\title{
Spontaneous regression of adrenal metastasis from renal cell carcinoma after sunitinib withdrawal: case report and literature review
}

\author{
Ti-Yuan Yang ${ }^{1,2}$, Wun-Rong Lin ${ }^{1,2^{*}}$ and Allen W. Chiu' ${ }^{1,2,3}$
}

\begin{abstract}
Background: The spontaneous regression of metastatic renal cell carcinoma is a rare phenomenon, with an estimated incidence of $<1 \%$. We report a case of post-nephrectomy renal cell carcinoma adrenal metastasis, followed by the spontaneous regression of the metastasis after withdrawal of sunitinib.

Case presentation: The patient was a 55-year-old male with clear cell type renal cell carcinoma who previously underwent a left laparoscopic radical nephrectomy. After 51 months of follow up, a recurrence in the left renal fossa was observed and subsequently excised. Four months after excision, an abdominal Computerized tomography (CT) identified an adrenal metastasis of $1.6 \mathrm{~cm}$. The patient was treated with sunitinib. However, the treatment was discontinued because of gastrointestinal side effects and fatigue. Eleven months after the discontinuation of sunitinib treatment, a progression in the adrenal metastasis growth $(5.7 \mathrm{~cm}$ ) was observed, whereas 16 months after the discontinuation, a regression of the adrenal metastasis growth $(3.4 \mathrm{~cm})$ was observed. During subsequent follow-ups, a gradual reduction in the size of the adrenal metastasis $(1.8 \mathrm{~cm})$ was observed. After 44 months from the discontinuation of sunitinib treatment, the patient was still alive and followed up in the outpatient department.

Conclusions: Sunitinib is a multi-targeted inhibitor of vascular endothelial growth factor (VEGF) receptors. This compound reduces tumor angiogenesis and has been approved worldwide for the treatment of advanced renal cell carcinoma. To our knowledge, this is the fourth case of the spontaneous regression of metastatic renal cell carcinoma after the discontinuation of sunitinib treatment.
\end{abstract}

\section{Background}

Approximately $21 \%$ of patients with renal cell carcinoma present with a metastatic disease at diagnosis, and $23 \%$ of patients who undergo radical nephrectomy for clinically localized disease develop metastasis/local recurrence during a 5-year follow-up [1]. The spontaneous regression of metastatic renal cell carcinoma is a rare but well-known phenomenon, with an estimated incidence of $<1 \%$ [2]. Several case reports have described the spontaneous regression of metastatic renal cell carcinoma. Such an occurrence has been associated with multiple different events that might influence the immune system, including primary

\footnotetext{
*Correspondence: vincent751051@gmail.com

'Department of Urology, Mackay Memorial Hospital, Taipei, Taiwan

${ }^{2}$ Department of Medicine, Mackay Medical College, Taipei, Taiwan

Full list of author information is available at the end of the article
}

tumor surgical debulking, radiation or embolization of the primary tumor, palliative hormonal treatment with tamoxifen, surgical abortion, and discontinuation of sunitinib treatment [3-6]. However, the exact mechanism remains unclear. We report a case of a post-nephrectomy adrenal metastasis of a renal cell carcinoma followed by the spontaneous regression of the metastasis after a short-term sunitinib treatment. To our knowledge, this is the fourth case of the spontaneous regression of metastatic renal cell carcinoma after withdrawal of sunitinib.

\section{Case presentation}

A 55-year-old man presented with chronic testicular pain. An ultrasonography of the abdomen detected left renal tumor. The patient had a history of hypertension and left renal urolithiasis. CT showed a heterogeneous

(c) The Author(s). 2018 Open Access This article is distributed under the terms of the Creative Commons Attribution 4.0 International License (http://creativecommons.org/licenses/by/4.0/), which permits unrestricted use, distribution, and 
left upper pole renal tumor (5.3 $\mathrm{cm}$ in diameter). A laparoscopic radical nephrectomy was performed in May 2008. Left adrenalectomy and lymph node dissection were not performed because the CT scan showed no adrenal gland invasion or lymphadenopathy. The histological evaluation of the tissue revealed a clear cell renal cell carcinoma and negative surgical margins (pathological stage, T2NOM0). Three years after nephrectomy, following a cerebrovascular accident, the Eastern Cooperative Oncology Group score changed from 0 to 2 . No tumor recurrence (CT scan was performed every 6 months) was found until 51 months later. A CT scan detected two nodules in the renal fossa $(1.8$ and $0.9 \mathrm{~cm}$, respectively). Retroperitoneal exploration confirmed recurrent clear cell carcinoma with microscopically positive surgical margins. Lymph node dissection was not performed because of severe adhesion around the aorta. Lymph nodes that could be detected by palpation were not identified during the surgery. Four months after excision, an abdominal CT showed a nodule $(1.6 \mathrm{~cm})$ over the right adrenal gland. At that time, tumor target therapy was not covered by the national health insurance in Taiwan. Therefore, because of economic reasons, the patient could not afford the treatment until 2013. A repeat CT evaluation confirmed the disease progression of the adrenal metastasis $(2.1 \mathrm{~cm})$. The patient was treated with sunitinib $(37.5 \mathrm{mg} / \mathrm{d})$ for 4 weeks, but the treatment was discontinued because of gastrointestinal side effects and fatigue. After 3 months, a CT scan showed the progression of the adrenal metastasis $(3.8 \mathrm{~cm})$ and no lower lung lesion. A chest X-ray revealed the absence of lung metastasis. The patient refused to undergo hormonal survey, biopsy, and adrenalectomy. Eleven months after sunitinib treatment, a CT scan showed an obvious growth of the adrenal metastasis $(5.7 \mathrm{~cm})$ (Fig. 1a), whereas 16 months after the treatment, a regression of the metastasis $(3.4 \mathrm{~cm}$ ) was observed (Fig. 1b). Twenty-two months after sunitinib treatment, a CT scan demonstrated a gradual reduction in the size of the adrenal metastasis $(1.8 \mathrm{~cm})$ (Fig. 1c). The patient was still alive and followed up at the outpatient department 44 months after the discontinuation of sunitinib treatment.

\section{Discussion and conclusions}

The spontaneous regression of cancer is defined as the partial or complete disappearance of a tumor without any treatment or with a treatment considered inadequate to exert a significant influence on the progression of cancer [7]. The spontaneous regression of metastatic renal cell carcinoma following nephrectomy was first described by Bumpus in 1928 [8]. It is a rare phenomenon, which is estimated to represent $<1 \%$ of renal cell carcinoma cases [9]. The regression of metastatic sites has been reported to occur at the lungs and at other visceral
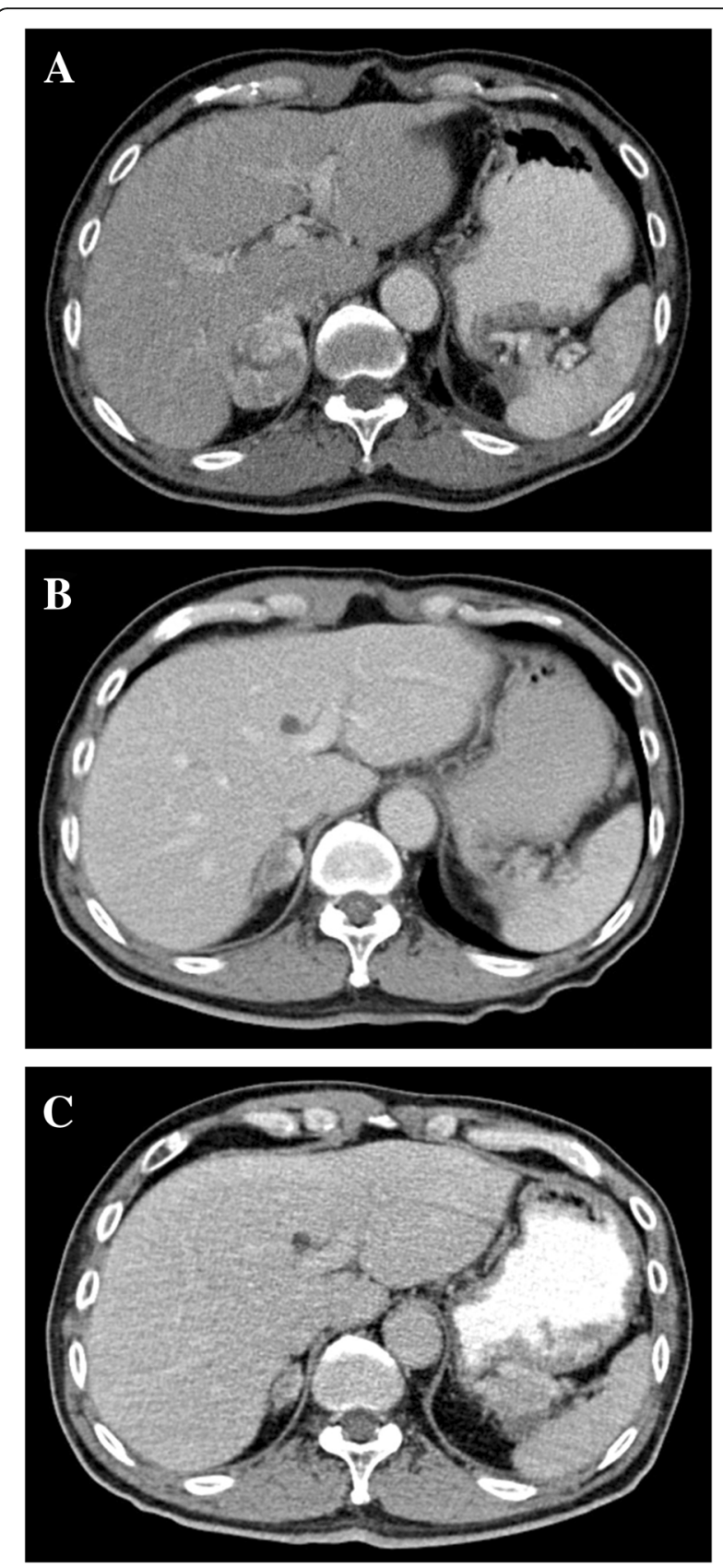

Fig. 1 Abdominal CT examination revealed spontaneous regression of adrenal metastasis (left to right). a. Adrenal metastasis measuring $5.7 \mathrm{~cm}$ in diameter. $\mathbf{b}$. Adrenal metastasis measuring $3.4 \mathrm{~cm}$ in diameter. c. Adrenal metastasis measuring $1.8 \mathrm{~cm}$ in diameter

organs including liver, bones, brain, choroid, pancreas, and adrenal glands [10]. The mechanism of the spontaneous regression of renal cell carcinoma remains unclear. Humoral, immunological, and vascular factors, such as autoinfraction, have been previously proposed to be possible pathophysiologic mechanisms [11]. Nephrectomy is not necessary and accounts for $<50 \%$ of the documented cases [12]. Because the oncologic benefits of lymph node 
dissection in the management of renal cell carcinoma remain controversial [13], we routinely performed nephrectomy and renal fossa recurrent tumor resection without lymph node dissection.

Sunitinib is a multi-targeted inhibitor of vascular endothelial growth factor (VEGF) receptors. The mechanism of action includes the reduction of tumor angiogenesis, which makes it an approved treatment for advanced renal cell carcinoma worldwide [14]. It has been shown that response rates are comparable among groups treated with $50 \mathrm{mg} / \mathrm{d}$ of sunitinib for 4 weeks followed by 2 weeks off treatment or with $37.5 \mathrm{mg} / \mathrm{d}$ of sunitinib on a continuous daily dosing treatment [15]. A study performed on 1059 patients treated with sunitinib for metastatic renal cell carcinoma has shown that 398 (38\%) patients had an objective response and $12(1.1 \%)$ had a complete response. The median time to tumor response was 10.6 weeks [16]. Our report describes the case of a patient who experienced metastasis progression after discontinuation of sunitinib treatment because of adverse effects on day 28 and spontaneous regression 16 months later. To our knowledge, there are only three other reports that have described a similar phenomenon. Rothermundt et al. reported a 63-year-old female patient who had a right renal tumor with the invasion of the right renal vein and the vena cava, bilateral adrenal metastasis, multiple lung metastases, and bone metastasis [17]. The patient was treated with $50 \mathrm{mg}$ of sunitinib 4 weeks on and 2 weeks of. A decrease in the size of all involved tumor sites was observed at the beginning of treatment. After 10 months, because an obvious disease was detected on $\mathrm{CT}$, sunitinib treatment was discontinued. A CT scan performed for trial purposes after 1 month revealed disease regression in all tumor locations. Yanagihara et al. were the second to report a case of the regression of metastatic renal cancer after the discontinuation of sunitinib treatment [18]. The authors reported the case of a 61-year-old female patient with a left renal tumor along with multiple bone and liver metastases. Left radical nephrectomy revealed disease progression in each metastatic site. The patient was treated with sunitinib, but the treatment was discontinued on day 11 because of thrombocytopenia and digestive symptoms. Disease regression was detected after 18 months. Teo et al. reported the case of a 65-year-old male patient [6] with lung metastasis, which was detected by CT scan 7 years after a right radical nephrectomy was performed for right renal cell carcinoma. Sunitinib was started for the metastasis. A partial response was achieved 9 months after starting the treatment; however, the treatment was discontinued because of disease progression after 6 months, which was followed by the regression of lung metastasis. The patient remains clinically well with a follow up of 44 months since the discontinuation of sunitinib treatment. A summary of the published cases of the discontinuation of sunitinib treatment is listed in Table 1. Data from three published cases and those from our patient showed that the interval of sunitinib treatment varied from 11 days to 15 months. The interval between spontaneous regression and the last sunitinib dose varied from 1 to 18 months. Two cases discontinued sunitinib treatment because of disease progression and two discontinued it because of the side effects of the drug.

The mechanisms of spontaneous regression after an incomplete use of the multiple kinase inhibitor sunitinib remain unclear. Rothermundt et al. drew an analogy with the antiandrogen withdrawal syndrome of prostate cancer. Gene mutations of the androgen receptor might be a possible mechanism of antiandrogen withdrawal syndrome, which cause the antiandrogens to act as partial agonists. A withdrawal of these antiandrogens can promote disease regression [19].

Another possible mechanism is the immunomodulatory effect of sunitinib. Sunitinib improved the type-1 T-cell cytokine response in patients with metastatic renal cell carcinoma while reducing the T-regulatory cell function [20]. Furthermore, sunitinib has been shown to inhibit the proliferation and function of human peripheral $\mathrm{T}$ cells and to prevent T-cell-mediated immune response in mice [21]. In the present report, sunitinib treatment, or its discontinuation, might have modified the immune response.

The phenomenon of spontaneous regression after the discontinuation of sunitinib treatment may be masked by further treatment. The disease regression might have been missed or attributed to other second line therapies if our patient had not refused the suggestion of a right

Table 1 Summary of published sunitinib withdrawal phenomenon cases

\begin{tabular}{|c|c|c|c|c|c|}
\hline Ref, year & Age/sex & Location & $\begin{array}{l}\text { Dose and length of } \\
\text { sunitinib treatment }\end{array}$ & $\begin{array}{l}\text { Reason for discontinuing } \\
\text { sunitinib treatment }\end{array}$ & $\begin{array}{l}\text { Interval between } \\
\text { spontaneous regression } \\
\text { and sunitinib }\end{array}$ \\
\hline Rothermundt, 2009 [17] & $63 / F$ & $\begin{array}{l}\text { bilateral adrenal glands, } \\
\text { lung and bone }\end{array}$ & $\begin{array}{l}\text { sunitinib } 50 \mathrm{mg} 4 \text { weeks on } \\
\text { and } 2 \text { weeks off, } 10 \text { months }\end{array}$ & disease progression & 1 month \\
\hline Yanagihara, 2011 [18] & $61 / F$ & bone and liver & sunitinib 50 mg per day, 11 days & $\begin{array}{l}\text { thrombocytopenia and } \\
\text { digestive symptoms }\end{array}$ & 18 months \\
\hline Teo, $2013[6]$ & $65 / M$ & lung & $\begin{array}{l}50 \mathrm{mg} / \mathrm{d}, 4 \text { weeks on and } 2 \text { weeks } \\
\text { off for } 6 \text { months and } 37.5 \mathrm{mg} \text { per } \\
\text { day for } 9 \text { months }\end{array}$ & disease progression & No mention \\
\hline
\end{tabular}


adrenalectomy. Thus, the number of patients with spontaneous regression associated with the discontinuation of sunitinib treatment may be underestimated, and this case report is a reminder of that for urologists.

Because recurrence has been reported after spontaneous regression [5], we will closely follow up our patient.

\section{Acknowledgements}

The authors are grateful to the operating room staff and ward staff of Mackay Memorial Hospital who participated in the management of this patient.

\section{Funding}

There are no sources of funding to be declared for this study.

\section{Availability of data and materials}

Data sharing not applicable to this article as no datasets were generated or analyzed during the current study.

\section{Authors' contributions}

WRL did the clinical evaluation of the patient, came to a diagnosis and operated on the patient. TYY and AWC participated literature review and wrote the manuscript. All authors read and approved the final manuscript to be published. All authors agreed to be accountable for all aspects of the work.

\section{Ethics approval and consent to participate}

Not applicable.

\section{Consent for publication}

We received written consent for publication from the patient

\section{Competing interests}

The authors declare that they have no competing interests.

\section{Publisher's Note}

Springer Nature remains neutral with regard to jurisdictional claims in published maps and institutional affiliations.

\section{Author details}

'Department of Urology, Mackay Memorial Hospital, Taipei, Taiwan.

${ }^{2}$ Department of Medicine, Mackay Medical College, Taipei, Taiwan. ${ }^{3}$ School of Medicine, National Yang-Ming University, Taipei, Taiwan.

Received: 14 May 2017 Accepted: 30 October 2018

Published online: 14 November 2018

\section{References}

1. Dabestani S, Thorstenson A, Lindblad P, Harmenberg U, Ljungberg B, Lundstam $S$. Renal cell carcinoma recurrences and metastases in primary non-metastatic patients: a population-based study. World J Urol. 2016;34(8): $1081-6$.

2. Nakajima $T$, Suzuki $M$, Ando $S$, lida T, Araki A, Fujisawa T, Kimura $H$. Spontaneous regression of bone metastasis from renal cell carcinoma; a case report. BMC Cancer. 2006;6:11.

3. Lekanidi K, Vlachou PA, Morgan B, Vasanthan S. Spontaneous regression of metastatic renal cell carcinoma: case report. J Med Case Rep. 2007;1:89.

4. Mangel L, Bíró K, Battyáni I, Göcze P, Tornóczky T, Kálmán E. A case study on the potential angiogenic effect of human chorionic gonadotropin hormone in rapid progression and spontaneous regression of metastatic renal cell carcinoma during pregnancy and after surgical abortion. BMC Cancer. 2015; 15:1013.

5. de Riese W, Goldenberg K, Allhoff E, Stief C, Schlick R, Liedke S, Jonas U. Metastatic renal cell carcinoma (RCC): spontaneous regression, long-term survival and late recurrence. Int Urol Nephrol. 1991;23(1):13-25.

6. Teo M, Downey FP, McDermott RS. Beyond the maths of biology: long-term spontaneous tumoral regression after sunitinib withdrawal. Clin Genitourin Cancer. 2013;11(2):198-200

7. Cole WH, Everson TC. Spontaneous regression of cancer: preliminary report. Ann Surg. 1956;144(3):366-83.
8. Bumpus HCJ. The apparent disappearance of pulmonary metastasis in a case of hypernephroma following nephrectomy. J Urol. 1928:20:185.

9. Kim H, Park BK, Kim CK. Spontaneous regression of pulmonary and adrenal metastases following percutaneous radiofrequency ablation of a recurrent renal cell carcinoma. Korean J Radiol. 2008;9(5):470-2.

10. Janiszewska AD, Poletajew S, Wasiutynski A. Spontaneous regression of renal cell carcinoma. Contemp Oncol (Pozn). 2013;17(2):123-7.

11. Kobayashi K, Sato T, Sunaoshi K, Takahashi A, Tamakawa M. Spontaneous regression of primary renal cell carcinoma with inferior vena caval tumor thrombus. J Urol. 2002;167(1):242-3.

12. Lokich J. Spontaneous regression of metastatic renal cancer. Case report and literature review. Am J Clin Oncol. 1997;20(4):416-8.

13. Gershman B, Thompson RH, Boorjian SA, Larcher A, Capitanio U, Montorsi F, Carenzi C, Bertini R, Briganti A, Lohse CM, et al. Radical nephrectomy with or without lymph node dissection for high-risk non-metastatic renal cell carcinoma: a multi-institutional analysis. J Urol. 2017;199:1143-8.

14. Motzer RJ, Hutson TE, Tomczak P, Michaelson MD, Bukowski RM, Rixe O, Oudard S, Negrier S, Szczylik C, Kim ST, et al. Sunitinib versus interferon alfa in metastatic renal-cell carcinoma. N Engl J Med. 2007;356(2):115-24.

15. Motzer RJ, Hutson TE, Olsen MR, Hudes GR, Burke JM, Edenfield WJ, Wilding G, Agarwal N, Thompson JA, Cella D, et al. Randomized phase II trial of sunitinib on an intermittent versus continuous dosing schedule as first-line therapy for advanced renal cell carcinoma. J Clin Oncol. 2012;30(12):1371-7.

16. Molina AM, Lin X, Korytowsky B, Matczak E, Lechuga MJ, Wiltshire R, Motzer RJ. Sunitinib objective response in metastatic renal cell carcinoma: analysis of 1059 patients treated on clinical trials. Eur J Cancer. 2014:50(2):351-8.

17. Rothermundt CA, Omlin A, Gillessen S. Sunitinib withdrawal phenomenon' or spontaneous regression in renal cell cancer. Ann Oncol. 2009;20(6):1144-6.

18. Yanagihara Y, Tanji N, Nishida T. Spontaneous regression of metastatic renal cancer after short-term treatment with sunitinib. Int J Urol. 2011;18(3):258-9.

19. Miyamoto H, Rahman MM, Chang C. Molecular basis for the antiandrogen withdrawal syndrome. J Cell Biochem. 2004;91(1):3-12.

20. Finke JH, Rini B, Ireland J, Rayman P, Richmond A, Golshayan A, Wood L, Elson P, Garcia J, Dreicer R, et al. Sunitinib reverses type-1 immune suppression and decreases T-regulatory cells in renal cell carcinoma patients. Clin Cancer Res. 2008;14(20):6674-82.

21. Gu Y, Zhao W, Meng F, Qu B, Zhu X, Sun Y, Shu Y, Xu Q. Sunitinib impairs the proliferation and function of human peripheral $T$ cell and prevents $T$ cell-mediated immune response in mice. Clin Immunol. 2010;135(1):55-62.

\section{Ready to submit your research? Choose BMC and benefit from:}

- fast, convenient online submission

- thorough peer review by experienced researchers in your field

- rapid publication on acceptance

- support for research data, including large and complex data types

- gold Open Access which fosters wider collaboration and increased citations

- maximum visibility for your research: over $100 \mathrm{M}$ website views per year

At $B M C$, research is always in progress.

Learn more biomedcentral.com/submission 